\title{
Pelusios sinuatus (Smith 1838) - Serrated Hinged Terrapin
}

\author{
Donald G. Broadley ${ }^{1}$ and Richard C. BoycotT ${ }^{2}$ \\ ${ }^{1}$ Biodiversity Foundation for Africa, \\ P.O.Box FM 730, Famona, Bulawayo, Zimbabwe [broadley@gatorzw.com]; \\ ${ }^{2}$ P.O. Box 5245, Mbabane, Swaziland [richjude@realnet.co.sz]
}

\begin{abstract}
Summary. - The serrated hinged terrapin, Pelusios sinuatus (Family Pelomedusidae), is the largest species in its genus (carapace length up to $55 \mathrm{~cm}$ ), with females larger than males. This is the typical deep water terrapin commonly found in the rivers and lakes of eastern Africa-large numbers can often be seen basking on suitable logs, rocks, mudbanks, or on the backs of sleeping hippopotami. During the rainy season these terrapins migrate overland and colonize isolated pans and waterholes. Nesting takes place at the beginning of the rainy season, October-November in southern Africa, but has also been recorded as late as April, with nests being excavated up to 500 $\mathrm{m}$ from the water. The clutch size varies from 7 to 30 eggs. The species exudes a foul odor when handled and is not currently exploitated and is not considered threatened, except for populations in polluted rivers downstream from industrialized areas.

Distribution. - Botswana, Burundi, Congo (DRC), Ethiopia, Kenya, Malawi, Mozambique, Rwanda, Somalia, South Africa, Swaziland, Tanzania, Zambia, Zimbabwe. Distributed in East Africa from southern Ethiopia and Somalia south to Swaziland and northern KwaZulu-Natal, South Africa, extending westwards to Lake Tanganyika and the upper Zambezi.

Synonymy.- Sternotherus sinuatus Smith 1838, Sternothaerus (Tanoa) sinuatus, Pelusios sinuatus, Pelusios sinuatus sinuatus, Sternotherus dentatus Peters 1848, Sternothaerus dentatus, Sternothaerus bottegi Boulenger 1895, Pelusios sinuatus zuluensis Hewitt 1927, Pelusios sinuatus leptus Hewitt 1933.

SuBSPECIES. - None currently recognized.

STatus. - IUCN 2009 Red List: Not Listed (= Least Concern, LR/lc) (assessed 1996, needs updating); CITES: Not Listed; South African Red Data Book: Not Listed.
\end{abstract}

Taxonomy. - Pelusios sinuatus was described as Sternotherus sinuatus by Andrew Smith (1838) from "rivers to the north of 25 degrees south latitude" (type locality restricted to the Crocodile-Marico confluence, Limpopo
Province, South Africa, by Broadley, 1981).Junior synonyms of P. sinuatus include Sternotherus dentatus Peters 1848, later placed in synonymy by its author (Peters 1882), and Sternothaerus bottegi Boulenger 1895 from Somalia, syn-

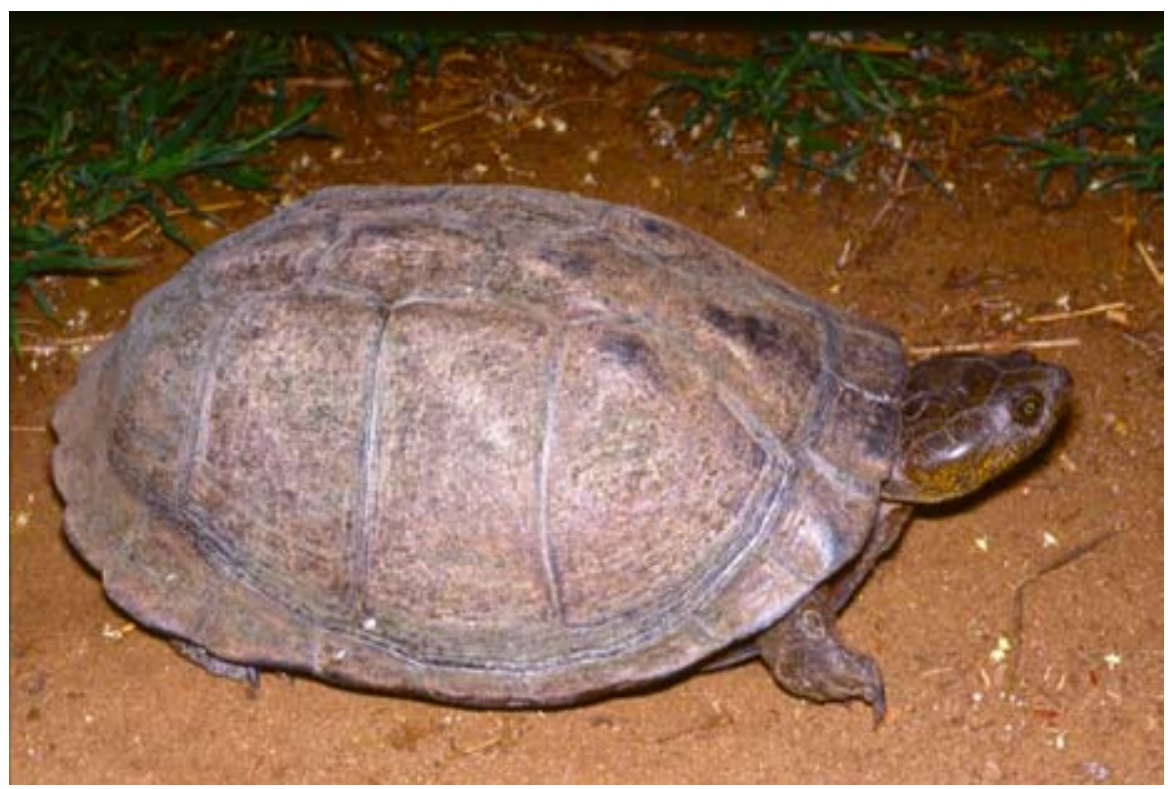

Figure 1. Pelusios sinuatus, adult female with a mass of $7 \mathrm{~kg}$ from Ndumu Game Reserve, northern KwaZulu-Natal, South Africa. Photo by R.C. Boycott. 


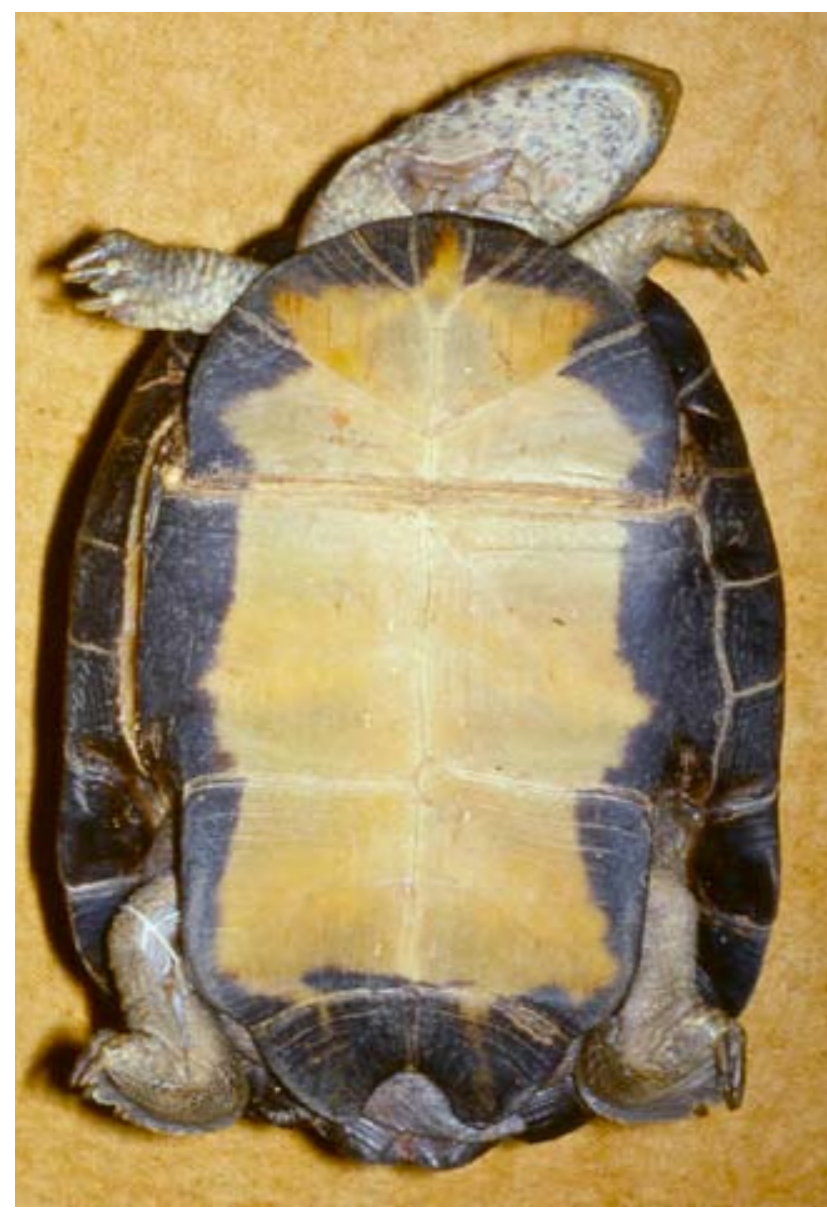

Figure 2. Pelusios sinuatus, adult female from Mpumalanga, South Africa. Photo by R.C. Boycott.

onymized by Siebenrock (1903) and confirmed by Loveridge (1941). The validity of this distinctive species has never been questioned, but two subspecies have been described. Pelusios sinuatus zuluensis Hewitt 1927 was described on the basis of a series from the Umsinene River, northern KwaZulu-Natal, which were distinguished from the typical form by well developed median protuberances on vertebrals 3 and 4 and their upturned posterior marginals, both variable

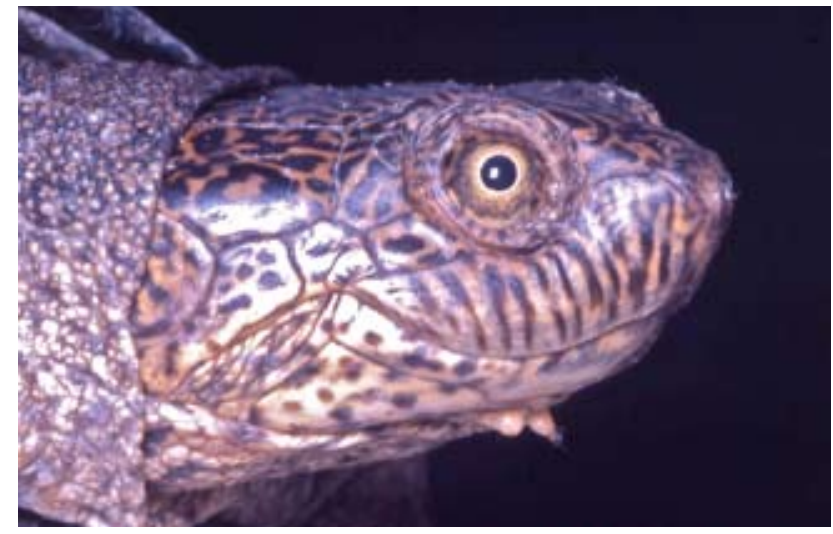

Figure 3. Pelusios sinuatus, $7 \mathrm{~kg}$ adult female from Ndumu Game Reserve, northern KwaZulu-Natal, South Africa. Photo by R.C. Boycott. characters in P. sinuatus. Pelusios sinuatus leptus Hewitt 1933 was described from an adult shell collected at Isoka in northeastern Zambia, and was distinguished by its narrow vertebral scutes, reduction in number of neural bones (5), and strong development of conical vertebral protuberances, especially on vertebral 4 . None of these characters proved diagnostic for either subspecies and consequently P. sinuatus was considered monotypic by Loveridge $(1936,1941)$ and subsequent authors. A preliminary morphologically-based phylogeny of the Pelomedusidae by Roger Bour (in Iverson et al.2007), suggested that $P$. sinuatus is most closely related to $P$. cupulatta and $P$. niger.

Description. - Pelusios sinuatus is a very large terrapin, with a carapace length (CL) reaching up to $46.5 \mathrm{~cm}$ in Lake Tanganyika (Witte 1952) and $55 \mathrm{~cm}$ in upland Kenya (Spawls et al. 2002). Females, with a typical CL of $40 \mathrm{~cm}$ and a mass of $7 \mathrm{~kg}$, grow much larger than males, which seldom exceed $35 \mathrm{~cm}$ and $4.5 \mathrm{~kg}$ (Boycott and Bourquin 2000). The shell is ovate in dorsal view, sub-triangular in cross section in juveniles and subadults, with the vertebrals strongly keeled (persisting in adults as posterior median protuberances on vertebrals 2,3 , and 4 ). The posterior marginals are strongly serrated in subadults, becoming sinuate in adults. The plastral hinge is well developed. This species is unique in having an axillary scute present, and the anterior plastral lobe is less than twice the length of the abdominal sulcus. A plastral concavity in males is poorly developed. The head is relatively small, much less than half the width of the plastron at the abdomino-femoral sulcus. The snout is rather pointed, with a bicuspid beak and a pair of mental barbels. Falciform scales on the forelimb are poorly developed.

Neural bones number from 5 to 7; N1 sometimes fails to reach the nuchal, N5 may be reduced in size or absent, leaving N6 isolated, N7 is often reduced in size or absent, N8 is always absent, so that the last two pairs of costal bones are in median contact.

The carapace and bridge are black (rarely dark brown) but often obscured by algal growth, the plastron is yellow with a sharply defined black peripheral pattern, sometimes also with several black chevrons mesially. Hatchlings have

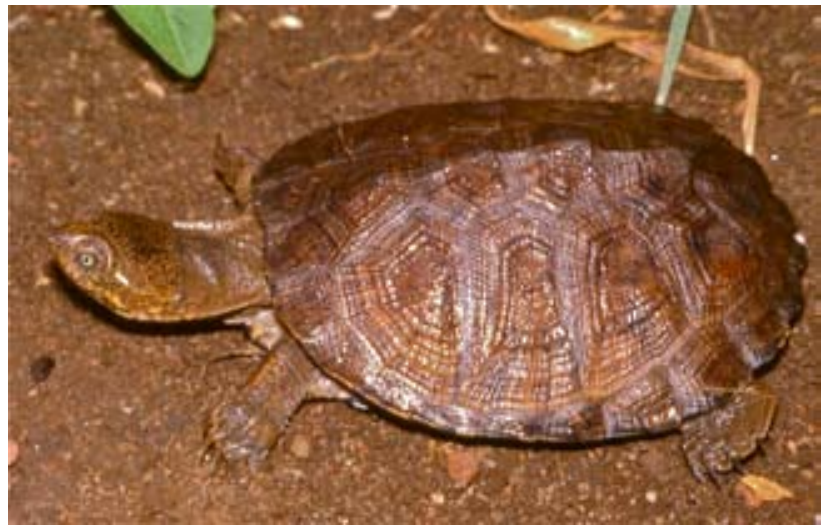

Figure 4. Pelusios sinuatus, juvenile from Balegane, northern Swaziland. Photo by R.C. Boycott. 


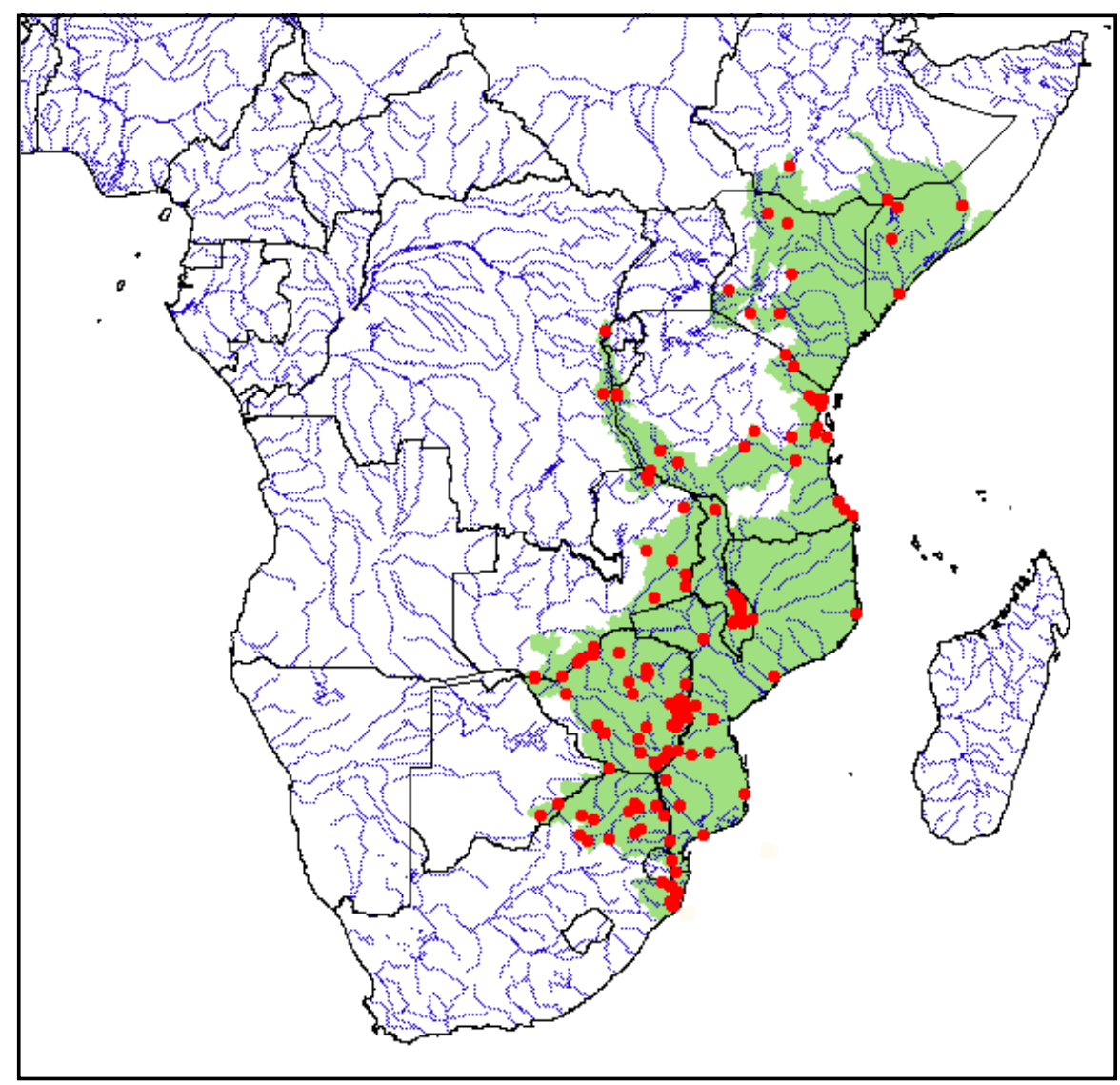

Figure 5. Distribution of Pelusios sinuatus in Africa. Red points = museum and literature occurrence records based on Iverson (1992) plus more recent and authors' data; green shading = projected distribution based on GIS-defined hydrologic unit compartments (HUCs) constructed around verified localities and then adding HUCs that connect known point localities in the same watershed or physiographic region, and similar habitats and elevations as verified HUCs (Buhlmann et al., in press), and adjusted based on authors' data.

the carapace brown and the plastron mottled salmon pink and gray. The head is blackish-brown with yellow or brown vermiculations, the skin of the neck and limbs is pale olivegray, and the outer faces of the limbs dark gray.

Males can be distinguished by their slightly longer tail, the tip (when folded to the side) extending to the seam between the tenth and eleventh marginal scutes, and the slight plastral concavity involving the posterior region of the abdominals and anterior region of the femorals. Distally the femoral scutes are slightly upturned in adult males.

Distribution. - Found from southern Ethiopia and Somalia (Lanza and Sassi 1966) south to Swaziland and South Africa, extending westwards to Lake Tanganyika and the Upper Zambezi (Katombora Rapids). The range was formerly much more extensive, as fossil specimens of $P$. sinuatus have been recorded from the Lower Pleistocene of Chad and Lake Turkana in Kenya (Broin 1969). In Pleistocene deposits at Olduvai Gorge in Tanzania, $98 \%$ of the chelonian fragments were P. sinuatus (Auffenberg 1981).

Habitat and Ecology. - This is the typical deep water terrapin found in the rivers and lakes of eastern Africa (but not recorded from Uganda) - large numbers can often be seen basking on suitable logs, rocks, or mudbanks (or even on the backs of sleeping hippopotami). During the rainy season these terrapins migrate overland and colonize isolated pans and waterholes. In Swaziland they have been recorded from man-made habitats such as farm dams, borrow pits, and quarries (Boycott 2001) indicating that they are not confined to large perennial rivers and lakes that represent the more typical habitat of the species. Above Victoria Falls, $P$. bechuanicus inhabits the clear water of the main Zambezi channels, while $P$. sinuatus is found in muddy lagoons and backwaters bordering the river. At some localities in Botswana (Jacobsen and van der Waal 1995) and eastern South Africa (Hoffman and van der Bank 2001), P. sinuatus has been recorded sympatrically with other species of terrapin, namely P. subniger and Pelomedusa subrufa. At the former, the habitat comprised a pool in a river bed, and at the latter a seasonally flooded pan. If a river dries up during a drought, $P$. sinuatus will estivate in cavities beneath tree roots on the river banks. Many of these terrapins are depredated and consumed by crocodiles (Crocodylus niloticus).

In defense, apart from relying upon the hinging plastron to protect the head and forelimbs once these have been withdrawn into the shell, these terrapins are capable of using their sharp claws and horny jaws to good effect. In addition, they have musk glands located ventrally in the soft skin next to the fourth and eighth marginal scutes from which a foul smelling secretion can be exuded or ejected (Boycott and Bourquin 2000). 
In Lake Malawi (Lake Nyasa), Malawi, P. sinuatus feeds almost entirely on large pulmonate snails with a shell almost $5 \mathrm{~cm}$ long: during the first 24 hours after capture, one of these terrapins may defecate up to three dozen of the opercula of these snails (Mitchell 1946). Aquatic insects, crabs, frogs, tadpoles, and fish are eaten. In Kruger National Park, South Africa, they scavenge from the carcasses of animals depredated by crocodiles and also take ticks from wallowing buffalos (Pienaar et al. 1983). These terrapins will also scavenge for bird nestlings that have fallen out of weaverbird nests overhanging the water. They are occasionally known to take floating fruit (Spawls et al. 2002).

Nesting takes place at the beginning of the rainy season, October-November in southern Africa, but has also been recorded as late as April (Boycott and Bourquin 2000), with nests being excavated up to $500 \mathrm{~m}$ from the water. The clutch size varies from 7 to 30 eggs measuring 42-45 x 24-26 mm with an average mass of 18-21 g (Boycott and Bourquin 2000). Nests are vulnerable to predation by the water monitor, Varanus niloticus, and the mongoose (Kyle and Mostert 1998). Hatchlings found in November - January have a CL of about $40 \mathrm{~mm}$. In southern Africa hatching has been recorded in March and April with hatchlings measuring 40-43 mm CL with a mass of 12-15 g (Boycott and Bourquin 2000).

Population Status. - Pelusios sinuatus is very common in suitable habitats throughout its range.

Threats to Survival. - Some populations, like those in Kruger National Park, South Africa, are threatened by industrial pollution of the headwaters of their river systems, but it is the entire aquatic ecosystem that is at risk. In Zimbabwe and Zambia this species is often caught by fishermen on rod and line, and the terrapins are eaten by some tribes. Carapaces can often be recovered from village middens. In Swaziland this species is occasionally sold at the roadside by Swazis (Boycott, pers. obs.). Loveridge (1941) recorded that at Ujiji in Tanzania "some natives admitted eating these terrapin, others scornfully denied doing so." However, the species does not appear to be significantly threatened at this time.

Conservation Measures Taken. - The species occurs in many National Parks and nature reserves throughout its range, including Nairobi in Kenya, Zambezi, Chizarira, Matusadona, Mana Pools, Hwange, and Gonarezhou in Zimbabwe (Broadley and Blake 1979), Malolotja, Hlane, Mbuluzi, Mlawula, Mkhaya, and Mhlosinga in Swaziland (Boycott 2001), and Kruger National Park and the Ndumu, Mkuzi, St. Lucia, and Hluhluwe-Umfolozi Game Reserves in South Africa.

The species is not listed on the current IUCN Red List, having been assessed as LowerRisk/least concern by the IUCN Tortoise and Freshwater Turtle Specialist Group in 1996.

Conservation Measures Proposed. - There should be stricter control over the disposal of industrial waste and the use of toxic chemicals in agriculture, which would benefit all animals as well as humans dependent on the rivers and freshwater resources of the area.
Captive Husbandry. - The species appears to thrive well in captivity and there are records of individuals living as captives for more than a decade (Boycott and Bourquin 2000). A captive female in Nairobi Snake Park laid a clutch of 27 eggs, ca. $35 \mathrm{~mm}$ in diameter, in a tank. These were incubated and hatched out in two months (Spawls et al. 2002). On 19 January 1995 a female excavated a nest 10-21 $\mathrm{cm}$ deep in sand in an enclosure at the St. Lucia Crocodile Centre, KwaZulu-Natal. The nest contained 25 eggs measuring ca. 44 x $25 \mathrm{~mm}$, which were removed and placed in an incubator. After 48 days 24 eggs hatched, the hatchlings had shell lengths from 40.5 to $42.8 \mathrm{~mm}$ and weighed 12 to $14.9 \mathrm{~g}$ (Anderson 1995).

Current Research. - We are unaware of any current work on the species.

Acknowledgments. - In Ndumu and Umfolozi Game Reserves, northern KwaZulu-Natal, several individuals assisted in the acquisition of specimens for photography. We thank Orty Bourquin, Peter Coulon, George Hughes, Garnot Jackson, Simon Struben, and Josh White.Anumber of people assisted with the collection of specimens in Swaziland: thanks to Roger Bills, Louis du Preez, Alister Gray, John Harding, Neil la Croix, Richard Tinsley, and Denis Tweddle for their enthusiastic assistance.

\section{LITERATURE CITED}

Anderson, N.B. 1995. Life history notes: Pelusios sinuatus: reproduction. African Herp News 23:49.

AUFFENBERG, W. 1981. The fossil turtles of Olduvai Gorge, Tanzania, Africa. Copeia 1981(3):509-522.

Boulenger, G.A. 1895. Esplorazione del Giuba e dei suoi affluenti compiuta dal Cap. V. Bottego durante gli anni 1892-93 sotto gli auspici della Società Geograpica Italiana. Risultati Zoologici. II, Rettili e Batraci. Annali del Museo Civico di Storia Naturale di Genova 35:9-18.

BoycotT, R.C. 2001. The terrapins and tortoises (Chelonia: Pelomedusidae and Testudinidae) of Swaziland. Durban Museum Novitates 26:25-37.

Boycott, R.C. And Bourquin, O. 2000. The Southern African Tortoise Book: A Guide to Southern African Tortoises, Terrapins and Turtles. O. Bourquin, Hilton, KwaZulu-Natal, South Africa, 228 pp.

Broadley, D.G. 1981. A review of the genus Pelusios Wagler in southern Africa (Pleurodira: Pelomedusidae). Occasional Papers of the National Museums and Monuments of Rhodesia Ser. B, Nat. Sci. 6(9):633-686.

Broadley, D.G. AND BlaKe, D.K. 1979. A check list of the reptiles of the National Parks and other conservation areas of Zimbabwe Rhodesia. Arnoldia Zimbabwe/Rhodesia 8(35):1-15.

BroIn, F. DE. 1969. Sur la presence d'une tortue, Pelusios sinuatus (A. Smith) au Villafranchien Inférieur du Tchad. Bulletin de la Société géologique de France 11(7):909-916.

Buhlmann, K.A., Akre, T.S., Iverson, J.B., Karapatakis, D., Mittermeier, R.A., Georges, A., Rhodin, A.G.J., van Dijk, P.P., AND GibBons, J.W. In press. A global analysis of tortoise and freshwater turtle distributions with identification of priority conservation areas. Chelonian Conservation and Biology 8(2): in press. 
HewITt,J. 1927.Further descriptions of batrachians and reptiles from South Africa. Records of the Albany Museum 3:371-415.

Hewit, J. 1933. Descriptions of some new reptiles and a frog from Rhodesia. Occasional Papers of the Rhodesian Museums 1: 45-50.

HoFFMAN,D. AND VAN DER BANK,H.2001.Pelusios subniger subniger - geographical distribution. African Herp News 32:34.

Iverson, J.B. 1992. A Revised Checklist with Distribution Maps of the Turtles of the World. Richmond, IN: Privately printed, $363 \mathrm{pp}$.

Iverson, J.B., Brown, R.M., Akre, T.S., Near, T.J., Le, M., Thomson, R.C., and Starkey, D.E. 2007. In search of the tree of life for turtles. In: Shaffer, H.B., FitzSimmons, N.N., Georges, A., and Rhodin, A.G.J. (Eds.). Defining Turtle Diversity: Proceedings of a Workshop on Genetics, Ethics, and Taxonomy of Freshwater Turtles and Tortoises. Chelonian Research Monographs No. 4, pp. 85-106.

Jacobsen, N.H.G. And van Der WaAl, B.C.W. 1995. Pelusios subniger subniger - geographical distribution. African Herp News 23:49.

Kyle, R. And Mostert, S. 1998. Some notes on breeding and on egg mortality in the serrated hinged terrapin Pelusios sinuatus, in Kwazulu-Natal, South Africa. Lammergeyer 45:39-40.

LANZA, B. AND SASSI, A. 1966. Le testuggini terrestri e d'acgua dolce della Somalia (Reptilia Testudines). Monitore Zoologico Italiano (Firenze) (Suppl.) 74:257-272.

LOVERIDGE, A. 1936. Reports on the scientific results of an expedition to rain forest regions in eastern Africa. V. Reptiles. Bulletin of the Museum.of Comparative Zoology 79:209-337.

Loveridge, A. 1941. Revision of the African terrapins of the family Pelomedusidae. Bulletin of the Museum of Comparative Zoology 88:465-524.

Mitchell, B.L. 1946. A naturalist in Nyasaland. Nyasaland Agricultural Quarterly Journal 6:1-47.
PetERs, W.C.H. 1848. Ueber eigenthümliche Moschusdrüsen bei Schildkröten. Archiv für Anatomie und Physiologie und wissenschaftliche Medicin 1848:492-496.

Peters, W.K.H. 1882. Naturwissenschaftliche reise nach Mossambique auf Befehl seiner Majestät des Königs Friedrich Wilhelm IV in den Jahren 1842 bis 1848 ausgeführt. Zoologie, 3, Amphibien. Berlin, $191 \mathrm{pp}$.

PienaAr, U. De V., HaAcke, W.D., And Jacobsen, N.H.G. 1983. The reptiles of the Kruger National Park. Pretoria: National Parks Board of Trustees.

Siebenrock, F. 1903. Zur Systematik der Gattung Sternothaerus Bell. Zoologische Anzeiger 26:191-199.

Smith, A. 1838. Illustrations of the Zoology of South Africa, consisting chiefly of Figures and Descriptions of the Objects of Natural History collected during an Expedition into the Interior of South Africa, in the years 1834, 1835, and 1836. Vol. 3. Reptilia. London: Smith, Elder \& Co., 28 pp.

Spawls, S., Howell, K., Drewes, R., and Ashe, J. 2002. A Field Guide to the Reptiles of East Africa: Kenya, Tanzania, Uganda, Rwanda and Burundi. San Diego: Academic Press, 543 pp.

WitTE, G.F. DE. 1952. Amphibiens et reptiles. Exploration Hydrobiologique du Lac Tanganyika (1946-1947). Vol. 3(3):1-22.

\section{Citation Format for this Account:}

Broadley, D.G. AND Boycott, R.C. 2009. Pelusios sinuatus (Smith 1838) - serrated hinged terrapin. In: Rhodin, A.G.J., Pritchard, P.C.H., van Dijk, P.P., Saumure, R.A., Buhlmann, K.A., Iverson, J.B., and Mittermeier, R.A. (Eds.). Conservation Biology of Freshwater Turtles and Tortoises: A Compilation Project of the IUCN/SSC Tortoise and Freshwater Turtle Specialist Group. Chelonian Research Monographs No. 5, pp. 036.1-036.5, doi:10.3854/crm.5.036.sinuatus.v1.2009, http://www.iucn-tftsg. org/cbftt/. 